\title{
Repeated penetrating corneal transplantation in patients with a previous tectonic transplant
}

\author{
Retransplante penetrante de córnea em pacientes \\ submetidos à transplante tectônico prévio
}

Paulo Rodolfo Tagliari Barbisan ${ }^{1}$, Rosane Silvestre de Castro ${ }^{2}$

\begin{abstract}
Objective: To analyze, in a university hospital of reference, the rate of a new penetrating corneal transplantation in patients that had previously undergone a tectonic keratoplasty and analyze the results after one year of surgery. Methods: Retrospective review of patients undergoing penetrating corneal transplantation, from november of 2010 to november of 2014. Comparative analysis of best corrected visual acuity (BCVA), intraocular pressure and corneal transparency before surgery and after one year, in the group of patients in which it was performed a re-graft after a failed tectonic transplantation. Results: A total of 318 patients underwent penetrating corneal transplantation during the study period. Of the 199 patients who underwent tectonic transplantation, 36 were subjected to re-graft and re-grafts were performed more than once in 2 eyes, with total of 38 transplants (19,09\%). The results showed improvement of BCVA in 20 (52.63\%), worsening in $8(21.05 \%)$ and unchanged in 10 (26.31\%); improvement of intraocular pressure in $3(7.89 \%)$, deterioration in $3(7.89 \%)$ and unchanged in 32 (84.21\%); improvement of corneal transparency 25 (65.78\%), worsening 4 (10.52\%) and 9 unchanged (23.68\%) patients. Conclusion: This study demonstrated a considerable number of repeated penetrating keratoplasty in patients with a history of failed tectonic corneal transplantation. In spite of bad prognosis in cases where there is high-risk corneal recipients and history of a failed tectonic transplant, there was improvement of the corneal transparency and best corrected visual acuity even after a year of surgery.
\end{abstract}

Keywords: Corneal transplantation; Penetrating keratoplasty

\section{RESUMO}

Objetivo: Analisar, em um hospital universitário de referência, a taxa de novo transplante penetrante de córnea em pacientes que já haviam realizado um transplante de córnea tectônica e analisar os resultados após um ano de cirurgia. Métodos: Análise retrospectiva dos prontuários de pacientes submetidos a transplante de córnea penetrante, a partir de novembro de 2010 a novembro de 2014. A análise comparativa da melhor acuidade visual corrigida, pressão intraocular e de transparência da córnea antes da cirurgia e após um ano, no grupo de pacientes em que foi realizado um retransplante após um transplante tectônico falho. Resultados: Foram avaliados 318 pacientes submetidos à ceratoplastia penetrante no período estudado. Dos 199 pacientes que realizaram transplante tectônico, 36 foram submetidos a re-enxerto e re-enxertos foram realizados mais de uma vez em 2 olhos, com total de 38 transplantes $(19,09 \%)$. A análise dos resultados mostrou melhora da melhor acuidade visual corrigida em 20 (52,63\%), piora em 8 (21,05\%) e inalterado em 10 (26,31\%); melhora da pressão intraocular em $3(7,89 \%)$, piora em $3(7,89 \%)$ e inalterado em 32 (84,21\%); melhora da transparência corneana em 25 (65,78\%), piora em 4 (10,52\%) e inalterado em $9(23,68 \%)$ pacientes. Conclusão: O estudo demonstrou um número considerável de retransplante penetrante de córnea em pacientes com história de transplante de córnea tectônico falho. Apesar do mau prognóstico nos casos com história de um transplante tectônico falho, houve melhora da transparência da córnea e da acuidade visual mesmo após um ano da cirurgia.

Descritores: Transplante de córnea; Ceratoplastia penetrante

\footnotetext{
${ }^{1}$ Universidade Estadual de Campinas (SP), Brasil;

${ }^{2}$ Hospital de Clínicas da Universidade Estadual de Campinas (Unicamp) (SP), Brasil.

Study conduced at Hospital de Clínicas da Universidade Estadual de Campinas (Unicamp).

The authors declare no conflicts of interests.

Received for publication 08/04/2015 - Accepted for publication 06/07/2015
} 


\section{INTRODUCTION}

$\mathbf{T}$ he success and excellent outcome of corneal transplantation is well known, especially when performed only once ${ }^{(1-6)}$. Corneal transplantation has a survival rate of $90 \%$ when performed in low-risk recipients ${ }^{(1)}$. Its high success rate can be attributed to the immune privilege of the cornea, including the absence of blood and lymphatic vessels in the cornea, the low expression of major histocompatibility (MHC) class I and II antigens on corneal cells, and anterior chamber-associated immune deviation ${ }^{(2)}$. However, the survival of transplants depends upon the condition of the recipient corneal bed ${ }^{(3)}$. In high-risk corneal recipients, such as those with severe infection or drilling eminence, inflamed or vascularized recipient beds and large-diameter or eccentric transplants, the tectonic corneal transplantation is a useful strategy for improving the condition of the recipient corneal beds, preserve the eyeball and to prolong the survival of future optical transplantations ${ }^{(4,5)}$. There is no specific data about repeated penetrating corneal transplantation after a previous failed tectonic transplantation and its outcomes. This study analyzes the rate of a new penetrating transplantation in patients, which had previously undergone a tectonic keratoplasty in a university hospital of reference and provide data of the results after one year of surgery.

\section{MethodS}

Retrospective review of medical records from patients who undergone penetrating corneal transplantation, from november of 2010 to november of 2014 at the Clinical Hospital of the state University of Campinas (Unicamp-Brazil), a university hospital of reference, and analysis of the clinical examination, evolution and outcomes of patients who underwent tectonic transplantation. Comparative analysis of best corrected visual acuity (BCVA), intraocular pressure and corneal transparency before surgery and after one year, in the group of patients in which it was performed a re-graft after a failed tectonic transplantation. Best corrected visual acuity (BCVA) improvement was established as gain of at least one line in the Snellen's visual acuity chart and worsening as loss of at least one line. Intraocular pressure improvement was determinate as decrease below of $21 \mathrm{mmHg}$ (in Goldmann's Tonometer) and worsening as increase above $21 \mathrm{mmHg}$. Corneal transparency improvement was established as reduction in corneal edema (in previously swollen corneas) and worsening as increase in corneal edema, formation of scars, stromal-deformities, folds and opacity.

\section{RESULTS}

Three hundred and eighteen patients who underwent penetrating corneal transplantation at the Clinical Hospital of the State University of Campinas (Unicamp-Brazil) in the period from november of 2010 to november of 2014 were evaluated. Among the 318 transplants, the primary causes for the indication were (table 1): 199 (62.58\%) tectonic transplantation, 65 (20.44\%) keratoconus, 23 (7.23\%) corneal dystrophies, 17 (5.35\%) bullous keratopathy and $14(4.40 \%)$ opacities/scars. Of the 199 patients who underwent tectonic transplantation, 36 were subjected to re-graft and re-grafts were performed more than once in 2 eyes, with total of 38 transplants $(19,09 \%)$. The primary reasons to conduct a re-graft in this group, were (table 2) rejection [24 patients $(63.16 \%)$ ], primary graft failure [8 patients $(21.05 \%)$ ] and recurrence of infection [6 patients $(15.79 \%)$ ]. Analysis of the re-graft showed (table 3) BCVA improvement in 20 (52.63\%), worsening in $8(21.05 \%)$ and unchanged in $10(26.32 \%)$; intraocular pressure improvement in $3(7.89 \%)$, worsening in 3 $(7.89 \%)$ and unchanged in $32(84.22 \%)$; corneal transparency improvement in $25(65.79 \%)$, worsening in $4(10.53 \%)$ and unchanged in $9(23.68 \%)$ patients.

Table 1

Causes of primary corneal transplantation

\begin{tabular}{lcr}
\hline \multicolumn{1}{c}{ Causes } & $\begin{array}{c}\text { Number of corneal } \\
\text { transplantation }\end{array}$ & Total\% \\
\hline Tectonic transplantation & 199 & 62.58 \\
Keratoconus & 65 & 20.44 \\
Corneal dystrophies & 23 & 7.23 \\
Bullous keratopathy & 17 & 5.35 \\
Opacities / Scars & 14 & 4.40 \\
Total & $\mathbf{3 1 8}$ & $\mathbf{1 0 0 . 0 0}$ \\
\hline
\end{tabular}

Table 2

Causes to conduct a re-graft after a failed tectonic transplantation

\begin{tabular}{lcc}
\hline \multicolumn{1}{c}{ Causes } & Number of re-grafts & Total\% \\
\hline Rejection & 24 & 63.16 \\
Primary graft failure & 8 & 21.05 \\
Recurrence of infection & 6 & 15.79 \\
Total & $\mathbf{3 8}$ & $\mathbf{1 0 0 . 0 0}$ \\
\hline
\end{tabular}

Table 3

Outcomes of corneal re-grafts

\begin{tabular}{lccc}
\hline \multicolumn{1}{c}{ Outcomes } & $\begin{array}{c}\text { Improvement } \\
\mathbf{N}(\%)\end{array}$ & $\begin{array}{c}\text { Worsening } \\
\mathbf{N}(\%)\end{array}$ & $\begin{array}{c}\text { Unchanged } \\
\mathbf{N}(\%)\end{array}$ \\
\hline $\begin{array}{l}\text { Visual acuity } \\
\begin{array}{l}\text { Intraocular } \\
\text { pressure }\end{array}\end{array}$ & $20(52.63)$ & $8(21.05)$ & $10(26.32)$ \\
$\begin{array}{l}\text { Corneal } \\
\text { transparency }\end{array}$ & $25(7.89)$ & $3(7.89)$ & $32(84.22)$ \\
\hline
\end{tabular}

\section{DisCUSSION}

In a university hospital of reference, there are high rates of tectonic transplants, since many patients are victims of trauma, corneal infection and corneal perforation. The primary objective of this study was to analyze the rate of a new penetrating corneal transplantation in patients that had previously undergone a tectonic keratoplasty. Our study demonstrated that the first keratoplasty is not always effective in maintaining the eye in good condition, controlling cases of infection or improve the optical bed for a future optical transplantation, showing a 19.09\% rate of new penetrating transplantation. Among the main causes that led these transplants to a new surgery, the rejection of the first 
transplant was the most common cause and this may be explained because in high-risk corneal recipients, such as those with inflamed or vascularized recipient beds, the immune privileges of the corneas are broken, so the survival rates of transplants fall to below $50 \%$, even with immune-suppression therapy ${ }^{(7-8)}$, being more susceptible to re-graft ${ }^{(9)}$. Due to the urgency in which transplants are performed, there is also a high rate of primary failure, because the eye bank's corneas used to perform the transplant, often are not optical corneas and are of a poorer quality. The success rate of tectonic keratoplasty for infectious keratitis is influenced by many factors, including microbial organism virulence, predisposing factors, extensiveness of pre-existing keratitis, associated ocular surface inflammation, initial medical treatment, and surgical techniques ${ }^{(5)}$. ${ }^{(5)}$. One of the serious problems in tectonic keratoplasty for infectious ulcer is postoperative recurrence of the infection and although penetrating keratoplasty is an effective approach to remove organisms for medically uncontrolled infectious ulcers, persistent and aggressive inflammation of previous transplants may not control the infection ${ }^{(11)}$ as we noted in 6 patients $(15.79 \%)$ that had to perform a new tectonic penetrating corneal transplantation due to recurrence of the previous infection. As in previous studies ${ }^{(12,14)}$, second and subsequent grafts in general fared poorly, but if they survived the first 3 postoperative years, then the failure rate decreased somewhat. Despite the basic analysis of clinical data after a year of surgery, $52.63 \%$ of the patients gain at least one line of BCVA in the Snellen's visual acuity chart and $65.79 \%$ showed corneal transparency improvement, despite having undergone a transplant aimed at preservation of the eyeball. Therefore, these results show that most patients have benefited from a repeated penetrating corneal transplantation, since there was improvement of the BCVA and transparency of the cornea.

\section{Conclusion}

Our study demonstrated a considerable number of repeated penetrating keratoplasty in patients with a history of failed tectonic corneal transplantation. In spite of bad prognosis in cases where there is high-risk corneal recipients and history of a failed tectonic transplant, there was improvement of the corneal transparency and best corrected visual acuity even after a year of surgery.

\section{REFERENCES}

1. Williams KA, Coster DJ. The immunobiology of corneal transplantation. Transplantation. 2007;84(7):806-13.

2. Huang T, Planck SR, Rosenbaum JT, Lee EJ. Feasibility study of lamellar keratoplasty in a murine model. Ocul Immunol Inflamm. 2009;17(4):257-64.

3. Ehlers N, Hjortdal J, Nielsen K. Corneal grafting and banking. Dev Ophthalmol. 2009;43(1):1-14.

4. Terry MA, Mark A. The evolution of lamellar grafting techniques over twenty-five years. Cornea. 2000;19(5):611-6.

5. Qu LJ, Xie LX. Changing indications for lamellar keratoplasty in Shandong, 1993-2008. Chin Med J (Engl) 2010;123(22):3268-71.

6. Patel NP, Kim T, Rapuano CJ, Cohen EJ, Laibson PR. Indications for and outcomes of repeat penetrating keratoplasty, 1989-1995. Ophthalmology. 2000;107(4):719-24.

7. Panda A, Vanathi M, Kumar A, Dash Y, Priya S. Corneal graft rejection. Surv Ophthalmol. 2007;52(4):375-96.
8. Williams KA, Lowe M, Bartlett C, Kelly TL, Coster DJ. Risk factors for human corneal graft failure within the Australian corneal graft registry. Transplantation. 2008;86(12):1720-4.

9. Bachmann B, Taylor RS, Cursiefen C. Corneal neovascularization as a risk factor for graft failure and rejection after keratoplasty: an evidence-based meta-analysis. Ophthalmology. 2010;117(7):13005.e7.

10. Ti SE, Scott JA, Janardhanan P, Tan DT. Therapeutic keratoplasty for advanced suppurative keratitis. Am J Ophthalmol. 2007;143(5):755-62.e2.

11. Yokogawa H, Kobayashi A, Yamazaki N, Masaki T, Sugiyama K. Surgical therapies for corneal perforations: 10 years of cases in a tertiary referral hospital. Clin Ophthalmol. 2014; 8:2165-70.

12. Bersudsky V, Blum-Hareuveni T, Rehany U, Rumelt S. The profile of repeated corneal transplantation. Ophthalmology. 2001;108(3):461-9.

13. Weisbrod DJ, Sit M, Naor J, Slomovic AR. Outcomes of repeat penetrating keratoplasty and risk factors for graft failure. Cornea. 2003;22(5):429-34.

14. Yildiz EH, Hoskins E, Fram N, Rapuano CJ, Hammersmith KM, Laibson PR, et al. Third or greater penetrating keratoplasties: indications, survival, and visual outcomes. Cornea. 2010;29(3):254-9.

\section{Autor correspondente:}

Rosane Silvestre de Castro

Rua Visconde do Rio Branco, $\mathrm{n}^{\circ} 630$ - Centro

CEP 13480-100 - Limeira (SP), Brazil

Tel: +55 (19) 34423475

E-mail: rosane@med-odonto.com.br 